\title{
Neurofibromatose Tipo 1: Envolvimento Cutâneo Exuberante
}

\section{Neurofibromatosis Type 1: Exuberant Cutaneous Involvement}

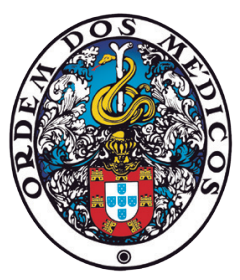

\author{
Sandra FERREIRA $\triangle^{1}$, Manuela SELORES ${ }^{1,2}$, Tiago TORRES ${ }^{1,2}$ \\ Acta Med Port 2020 Feb;33(2):149-149 - https://doi.org/10.20344/amp.12054
}

Palavras-chave: Doenças da Pele; Neurofibroma; Neurofibromatose tipo 1

Keywords: Neurofibroma; Neurofibromatosis 1; Skin Diseases

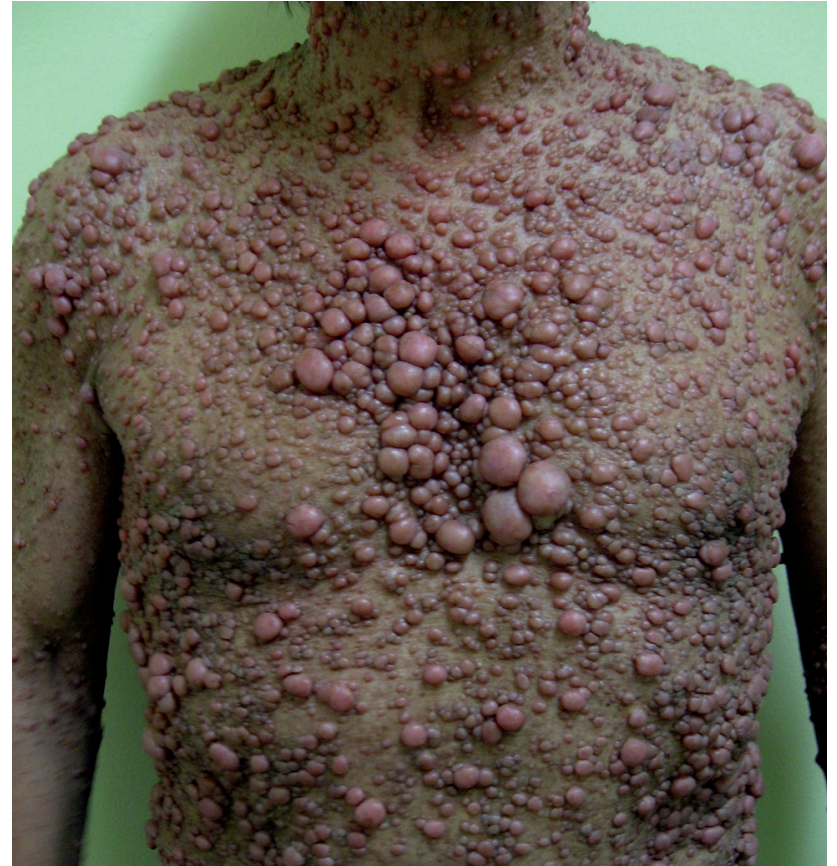

Figura 1 - Múltiplos neurofibromas no tronco (face anterior)

Homem de 54 anos com neurofibromatose tipo 1 (NF1), de início na infância com o aparecimento de múltiplas máculas hiperpigmentadas cutâneas e, posteriormente, na adolescência e idade adulta, de múltiplos nódulos e tumores (neurofibromas) ${ }^{1,2}$ envolvendo toda a superfície cutânea, alguns de grandes dimensões (Fig.s 1 e 2). Adicionalmente, apresentava alguns hamartomas pigmentados (nódulos de Lisch) ${ }^{3}$ em ambas as íris sem atingimento da acuidade visual, e escoliose ligeira, sem impacto na vida do doente.

A NF1 é um distúrbio genético autossómico dominante raro

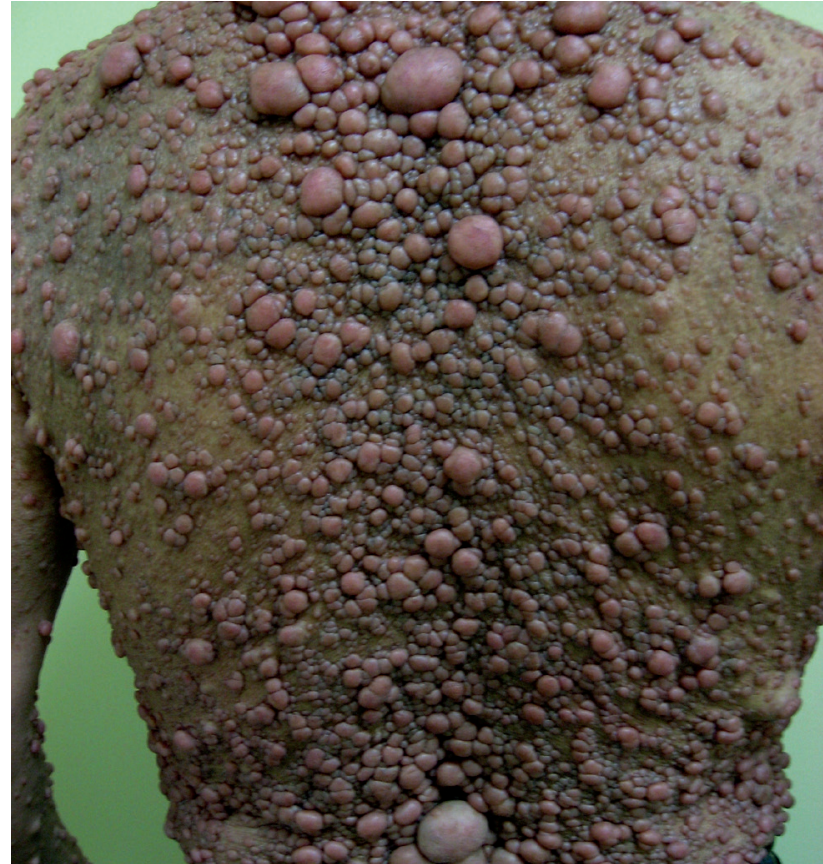

Figura 2 - Múltiplos neurofibromas no tronco (face posterior) com início habitual na primeira infância. Para além das manifestações apresentadas pelo nosso doente, podem igualmente observar-se efélides axilares e/ou inguinais, lesões esqueléticas, tumores cerebrais e do sistema nervoso periférico, e défice cognitivo. Os neurofibromas cutâneos são benignos, mas habitualmente representam um problema estético como no caso descrito, sendo o tratamento cirúrgico a melhor opção.

O prognóstico é bom, apesar da esperança média de vida poder ser diminuída até oito anos, essencialmente pelas manifestações extra-cutâneas. ${ }^{4,5}$

PROTECÇÃO DE PESSOAS E ANIMAIS: Os autores declaram que os procedimentos seguidos estavam de acordo com os regulamentos estabelecidos pelos responsáveis da Comissão de Investigação Clínica e Ética e de acordo com a Declaração de Helsínquia da Associação Médica Mundial.

CONFIDENCIALIDADE DOS DADOS: Os autores declaram ter seguido os protocolos do seu centro de trabalho acerca da publicação de dados

CONSENTIMENTO INFORMADO: Obtido.

CONFLITOS DE INTERESSE: Os autores declaram não ter qualquer conflito de interesse relativamente ao presente artigo.

FONTES DE FINANCIAMENTO: Não foi utilizada nenhuma bolsa ou subsídio para a realização do trabalho.

\section{REFEREENCIAS}

1. Lott IT, Richardson EP Jr. Neuropathological findings and the biology of neurofibromatosis. Adv Neurol. 1981;29:23

2. DeBella K, Szudek J, Friedman JM. Use of the national institutes of health criteria for diagnosis of neurofibromatosis 1 in children. Pediatrics. 2000;105:608

3. Lubs ML, Bauer MS, Formas ME, Djokic B. Lisch nodules in neurofibromatosis type 1. N Engl J Med. 1991;324:1264-6.

4. Evans DG, Baser ME, McGaughran J, Sharif S, Howard E, Moran A. Malignant peripheral nerve sheath tumours in neurofibromatosis 1. J Med Genet. 2002;39:311-4.

5. Ferrari A, Bisogno G, Macaluso A, Casanova M, D'Angelo P, Pierani $P$, et al. Soft-tissue sarcomas in children and adolescents with neurofibromatosis type 1. Cancer. 2007;109:1406.

1. Serviço de Dermatologia. Hospital de Santo António. Centro Hospitalar Universitário do Porto. Porto. Portugal.

2. Unidade de Investigação em Dermatologia. Hospital de Santo António. Centro Hospitalar Universitário do Porto. Porto. Portugal.

$\triangle$ Autor correspondente: Sandra Ferreira. mf.sandraferreira@gmail.com

Recebido: 15 de março de 2019 - Aceite: 29 de abril de 2019 | Copyright @ Ordem dos Médicos 2020 